\title{
Co-management of Traditional Foods: Opportunities and Limitations for Food Security in Northern First Nation Communities
}

\author{
Ainslie Cruickshank, ${ }_{1}^{1}$ Geranda Notten, ${ }^{1}$ Sonia Wesche, ${ }^{2}$ Kate Ballegooyen ${ }^{3}$ and Geraldine Pope ${ }^{3}$
}

(Received 1 May 2018; accepted in revised form 14 May 2019)

\begin{abstract}
Traditional foods that First Nations peoples harvest or gather from the land remain critically important for achieving and sustaining food security for many communities. In Canada's North, land claim agreements include provisions for First Nations to participate in the governance of their traditional territories, including the co-management of important traditional (wild-harvested) food species. Because such agreements only specify the broad contours of co-management governance, their actual functioning evolves out of a complex interplay among the co-managing organizations over the course of time. This paper aims to deepen our understanding of how First Nations communities can enhance food security as participants in co-management. Our study connects research on food security with research on co-management and is the first to analyze how First Nations can improve their food security by influencing decision-making that affects traditional foods through co-management arrangements. Following a succinct review of the Indigenous food security and co-management literatures, we analyze the experiences of Kluane First Nation in enhancing community food security through the co-management of its traditional territory with Yukon Government and Parks Canada, interpreting the data in light of the theories and evidences offered by research on co-management. The analysis of data collected from semi-structured interviews and from First Nations and government resources shows that, while the co-management system is imperfect, it does offer a mechanism through which First Nations can exert influence on decisions that affect their food security. The three key themes emerging from the excerpts confirm the importance of co-management as an evolutionary and long-term process, in which trust- and relationship-building are ongoing activities that are fundamental to beneficial collaboration involving the sharing of information and power. The analysis also highlights the role of context, or situational factors, in facilitating or hindering collaboration.
\end{abstract}

Key words: food security; traditional food; First Nations; Indigenous; co-management; governance; North; Yukon; Canada

RÉSUMÉ. Pour de nombreuses collectivités, les aliments traditionnels que les peuples des Premières Nations récoltent ou recueillent sur la terre continuent de revêtir une importance primordiale pour atteindre et maintenir la sécurité alimentaire. Dans le Nord canadien, les ententes de revendications territoriales comprennent des dispositions selon lesquelles les Premières Nations peuvent jouer un rôle dans la gouvernance de leurs territoires traditionnels, ce qui comprend la cogestion des espèces alimentaires (sauvages et cueillies) traditionnelles importantes. Puisque ces ententes ne font mention que des grandes lignes de la gouvernance en cogestion, leur fonctionnement est le résultat, en réalité, d'une interaction complexe entre les organismes de cogestion au fil du temps. Cet article cherche à mieux comprendre comment les collectivités des Premières Nations peuvent améliorer leur sécurité alimentaire à titre de participants à la cogestion. Notre étude fait le lien entre les recherches sur la sécurité alimentaire et les recherches sur la cogestion. Il s'agit de la première étude qui analyse la manière dont les Premières Nations peuvent améliorer leur sécurité alimentaire en influençant les décisions qui ont des incidences sur les aliments traditionnels, et ce, par le biais d'accords de cogestion. Après un examen succinct de la documentation qui existe au sujet de la sécurité alimentaire et de la cogestion, nous analysons l'expérience de la Première Nation de Kluane en matière d'amélioration de la sécurité alimentaire de la collectivité grâce à la cogestion de son territoire traditionnel avec le gouvernement du Yukon et Parcs Canada, puis nous interprétons les données à la lumière de théories et d'éléments de preuve découlant de travaux de recherche sur la cogestion. L'analyse des données recueillies à partir d'entrevues semi-structurées auprès de Premières Nations et de gouvernements montre que bien que le système de la cogestion soit imparfait, il offre un mécanisme permettant aux Premières Nations d'exercer une influence sur les décisions touchant leur sécurité alimentaire. Les principaux thèmes qui émergent de ces influences confirment l'importance de la cogestion à titre de processus évolutionnaire à long terme, dans le cadre duquel l'édification de la confiance et la conclusion de relations constituent des aspects fondamentaux en vue d'une

\footnotetext{
${ }^{1}$ Graduate School of Public and International Affairs, University of Ottawa, 120 University, Ottawa, Ontario K1N 6N5, Canada

${ }^{2}$ Corresponding author: Department of Geography, Environment and Geomatics, University of Ottawa, 60 University, Ottawa, Ontario K1N 6N5, Canada; Swesche@uottawa.ca

${ }^{3}$ Kluane First Nation, PO Box 20, Burwash Landing, Yukon Y0B 1V0, Canada

(C) The Arctic Institute of North America
} 
collaboration bénéfique fondée sur le partage de l'information et du pouvoir. Par ailleurs, notre analyse met en évidence le rôle du contexte, ou les facteurs situationnels, qui facilitent la collaboration ou lui nuisent.

Mots clés : sécurité alimentaire; aliments traditionnels; Premières Nations, Autochtones; cogestion; gouvernance; Nord; Yukon; Canada

Traduit pour la revue Arctic par Nicole Giguère.

\section{INTRODUCTION}

A range of stressors challenges the integrity of food systems in Canada's North, contributing to elevated rates of food insecurity within First Nations communities. Residents rely on a mix of market (store-bought) and traditional (wild-harvested) foods; however, traditional foods remain critically important, particularly in the context of limited access and prohibitive market food costs (Loring and Gerlach, 2015). Traditional foods provide a host of economic, social, dietary, cultural, and spiritual benefits (Loring and Gerlach, 2009); thus, maintaining ongoing availability of and access to key traditional food species is vital for ensuring food security.

Over the past decades, modern land claim agreements in Canada's North have led to the creation of co-management boards, which include First Nations representation. Co-management arrangements are a form of collaborative governance for managing common-pool resources such as lands, water, fish, and wildlife, where control and authority is shared in some measure by governments and resource users (Carlsson and Berkes, 2005; Reed, 2008; Berkes, 2009). Replacing the former top-down model of decision making, co-management allows the potential for First Nations to exert greater influence on policies and processes to manage the resources that support their traditional food systems (Loring and Gerlach, 2015).

Land claim agreements, however, only specify the broad contours of relevant co-management arrangements. Co-management scholars have found that the actual workings of such regimes evolve out of a complex interplay among the co-managing partners over the course of time (Berkes, 2007; Armitage et al., 2009). Given the prevalence of co-management arrangements and their potential relevance for food security, it is surprising that very few studies on First Nations food security mention co-management as a mechanism through which food security can be enhanced (e.g., ICCA, 2015; Rosol et al., 2016), and analyses of the actual workings of such arrangements are limited. To better understand how participation in co-management arrangements can help or hinder First Nations in achieving the goal of food security, this study investigates the experiences of the Kluane First Nation (KFN) in co-managing its traditional territory with the Yukon Government (YG) and Parks Canada.

This research uses theories and evidence from existing literature on co-management to interpret and analyze case study data from KFN in the context of food security. To understand the multiple perspectives on co-management of lands and wildlife in the area, our analysis focused on data from semi-structured interviews with political leaders, policymakers, and First Nations residents involved in these processes. Further, First Nations and government resources-including legislation, policy documents, and websites - were used to provide a more holistic context and interpretation. Our research shows that while the co-management system is imperfect, it does offer a mechanism through which First Nations can exert influence on decisions that affect their food security.

\section{FIRST NATIONS FOOD SECURITY, TRADITIONAL FOODS, AND CO-MANAGEMENT}

To provide a framework for this study, this section reviews the literature on both Indigenous food security (including First Nations, Inuit, Métis, and other global Indigenous groups) and co-management, and discusses how the latter can contribute to improving the former.

People, both individually and collectively, are deemed to be food secure when they "at all times, have physical, social, and economic access to sufficient, safe, and nutritious food which meets their dietary needs and food preferences for an active and healthy life" (FAO, 2015:53). Northern food security is predicated on four "pillars" and their stability over time. Namely, food must be available (supplied in the store or on the land), accessible (obtainable through physical, economic, social, or other means), of good quality (safe for consumption and of sufficient nutritional value), and usable (based on available food knowledge and skills, food equipment, and cultural preferences) (FAO, 1996; Wesche and Chan, 2010; Nunavut Food Security Coalition, 2014; Kenny et al., 2018). For northern First Nations, the traditional food system plays a significant role (Loring and Gerlach, 2009; Walch et al., 2018). As such, traditional food security requires the "continued and predictable availability and access to food, derived from northern environments through Indigenous cultural practices" (Paci et al., 2004:1), and recognizes that maintaining traditional food systems and practices is not only important for dietary quality, but also for cultural reasons (Lambden et al., 2007; HSS, 2010; Kral et al., 2011; CCA, 2014; Desmarais and Wittman, 2014; $\mathrm{KFN}$, 2014). For KFN members, for instance, "hunting is synonymous with life itself" (Nadasdy, 2003:63). Many still live by a modified version of the "annual round" of harvesting activities that they historically followed as seminomadic people. 
...at a certain time in May, everyone is suddenly "hungry for grayling," and they head en masse for the creek where they run. Soon after that, gophers emerge from their hibernation; everyone is "hungry for gophers," and they head to Duke Meadow to set traps for them. And so it continues through the year-the annual round in modified form.

(Nadasdy, 2003:68, 71)

It is due to this continued reliance on traditional foods for both cultural and nutritional reasons that we have undertaken research exploring the opportunities that might exist for KFN to assert greater influence within the co-management system over policies that affect access to and availability of these foods.

Rates of food insecurity in northern Indigenous communities are not only much higher than in the general population, but there is also a broadly shared concern that climate change is further stressing local food systems (CCA, 2014; IPCC, 2014). In a meta-analysis of the peerreviewed literature on food security in northern North America, remoteness, high food and fuel costs, and climate change were identified as important factors driving food insecurity; however, governance and policy were highlighted as the primary drivers (Loring and Gerlach, 2015). While emphasizing the time-tested ability of northern peoples to effectively respond to environmental changes, barriers to access created by existing governance and policy regimes "were the most commonly raised issue for food security in the region" (Loring and Gerlach, 2015:386).

More specifically, food security scholars have identified top-down decision making (Loring et al., 2011; Loring and Gerlach, 2015), excessive regulation (Reedy, 2016), insufficient regulation (Theriault et al., 2005), and un(der)developed social networks with decision makers (McConney et al., 2015) as causes of food insecurity. For governance and policy to act as positive drivers for northern Indigenous food security, the emerging paradigm underscores the need for more collaborative governance and more inclusive, locally-driven decision making.

Proponents of the related food sovereignty movement emphasize "that decisions about food systems should be made by those who depend on them" (CCA, 2014:13). Popularized by the international peasant organization, Via Campesina, in the context of agricultural societies, food sovereignty entails "the right of each nation to maintain and develop its own capacity to produce its basic foods respecting cultural and productive diversity" (Jarosz, 2014:173). There are now several organizations in Canada approaching food sovereignty from an Indigenous perspective, with a focus on traditional foods (Desmarais and Wittman, 2014). In the northern context, movement toward food sovereignty requires that Indigenous communities be involved in land, wildlife, and resource policy decisions that affect local food systems.
Over the past few decades, modern land claim agreements with Inuit and First Nations groups in Canada's North have given rise to the institutionalization of new governance arrangements that involve Indigenous representatives in decision-making processes regarding wildlife, resource development, and conservation on their traditional territories (Berkes, 2009; Natcher, 2013; Staples and Natcher, 2015). While these agreements offer a formal framework for more collaborative and local governance, they do not give Indigenous groups the degree of decisionmaking power over their traditional territories warranted by a strong definition of food sovereignty (see case study context for further explanation of the new governance structure). We use the term "food security" because the concept better aligns with our research aim, which is to understand how First Nations can and do use the present governance structure to improve the continued availability of and their access to traditional foods. Adopting the concept of food sovereignty would also naturally expand the focus to include changing the formal governance structure. While this is a very important subject, the present system, achieved through decades-long negotiations (with some negotiations still ongoing), may not see any formal changes in the foreseeable future.

At present, there are no studies on food security that analyze in what form and to what extent collaborative and more localized governance regimes help to achieve food security in general, and specifically, in northern First Nations communities (Loring and Gerlach, 2015). This research contributes to filling this gap by analyzing how First Nations communities try to enhance their food security as participants in collaborative and more localized governance arrangements, thereby also assessing to what degree and under which circumstances such participation helps or hinders the achievement of food security. In our analysis, we apply theories and evidence from research on co-management to the context of First Nations food security. Co-management scholars define co-management as a collaborative governance approach for managing common-pool resources, such as land, water, fish, and wildlife (Carlsson and Berkes, 2005; Reed, 2008; Berkes, 2009) within a structure that involves the "sharing of power and responsibility between the government and local resource users" (Berkes et al., 1991:12). Numerous studies have evaluated the successes and failures of co-management in achieving goals such as conservation, environmental resilience, sustainable resource use, and successful livelihood strategies (e.g., Berkes, 2007, 2009; Armitage et al., 2009; Evans et al., 2011; Wamukota et al., 2012); however, there has been limited focus on the goal of food security to date.

The food security literature includes only a few publications that specifically mention co-management as a mechanism through which food security can be enhanced. Furthermore, none of these studies examine the actual workings of such arrangements. In their investigation of nutrient intake among the Inuit in Canada's Arctic, 
Rosol et al. (2016) suggest that a co-management agency may help increase access to traditional foods. The food security report published by the Inuit Circumpolar Council-Alaska specifically mentions co-management as a tool to support environmental health, which in turn, is key to achieving food security (ICCA, 2015). Tapping into the rich knowledge from the co-management literature, which also includes many studies analyzing the governance of common-pool resources in northern communities, thus seems a promising avenue to learn how this more collaborative and more localized governance in northern Canada can contribute to First Nations food security. Moreover, the insight that First Nations representatives in Canada could use the language of food security and identify it as a target outcome in their efforts to exercise influence on decision-making through the new governance bodies is relatively recent. Finally, a better understanding of how to achieve food security through current governance arrangements in northern Canada is also relevant for co-management research because the choice of target outcomes may also influence the stability and success of the governance arrangement (for instance, through shifts in the balance of power between participants or additional opportunities for coalition building).

The co-management literature analyzes collaborative governance arrangements that are diverse, complex, and dynamic. Some arrangements are successful while others are not, thus requiring an in-depth understanding to assess the conditions under which an arrangement may be successful (Berkes, 2007). Over recent decades, co-management research has highlighted that such arrangements have different dimensions (Berkes, 2007). Some dimensions focus on the desired outcome or consequences of co-management such as institution building, trust building, problem solving, and social learning, while other dimensions focus on the nature of the arrangement, namely power sharing, process, and governance. The different dimensions of a co-management arrangement are interdependent. Power sharing, for instance, is the result of a continuous problem-solving process involving joint learning (Carlsson and Berkes, 2005). A more recent insight in the literature is that co-management arrangements are adaptive and must evolve to become and remain successful (Berkes, 2007, 2009; Armitage et al., 2009). Through cycles of learning-bydoing, maturing arrangements become adaptive over time. Those that do not adapt often fail (Berkes, 2009).

In managing common-pool resources, co-management arrangements may capture benefits that top-down arrangements cannot (Feeny et al., 1990; Ostrom, 1990; Carlsson and Berkes, 2005). Potential benefits include the distribution of tasks, the exchange of resources, coordination of actions through the linking of different types and levels of organization, the reduction of transaction costs, the sharing of risks, and the use of conflict resolution mechanisms (Carlsson and Berkes, 2005).
The co-management literature stresses both the importance of context and of more controllable factors in contributing to successful co-management arrangements. Ostrom (1990) identifies a range of situational factors that influence the likelihood that a decentralized governance arrangement such as co-management arises and endures: size of the common-pool resource and its current state, number of users, heterogeneity of user interests, relational connections among users, skills and assets of leaders, and history (e.g., conflict, past strategies of users). Adaptive co-management scholars Armitage et al. (2009) echo some of these environmental conditions as relevant for successful adaptive co-management; however, they also identify factors that can be altered or influenced, such as the commitment to support a long-term institutionbuilding process, the provision of training and resources for stakeholders, an openness of participants to share and draw upon a plurality of knowledge systems and resources, and a policy environment that explicitly supports collaborative management efforts. Berkes (2009) further identifies a range of strategies that have been shown to foster collaborative, participatory, democratic, and accountable relationships among diverse stakeholders. These include participatory research, the co-production of knowledge, and collaborative monitoring.

In the context of Canada's North, Nadasdy (2003) rightly cautioned against uncritical acceptance of co-management successes, and numerous challenges have been identified during the early years of these regimes (Stevenson, 2004; Nadasdy, 2005). However, much of the recent literature continues to be excessively critical and overlooks the significant gains that have been and continue to be made in this realm (Clark and Joe-Strack, 2017). Co-management is not easy, and current regimes in the North may fall short of the nation-to-nation relationship ideal; however, they do offer a formal and evolving space for local participation in policy development and implementation.

Research indicates that co-management arrangements take years if not decades to develop, and most successful efforts transpire under the umbrella of a (conducive) formal arrangement (Ostrom 1990; Berkes, 2007; Armitage et al., 2009). The co-management literature thus offers a valuable theoretical lens through which to deepen our understanding of how local participants in Canada's northern co-management bodies can increase their influence within the present system to strengthen food security. In the results and discussion section of this paper, we rely on this literature to interpret and discuss the findings from our KFN case study.

\section{METHODOLOGY}

\section{Study Location}

KFN is based in Burwash Landing, a small community of 108 people (Yukon Government, 2017) located $285 \mathrm{~km}$ 


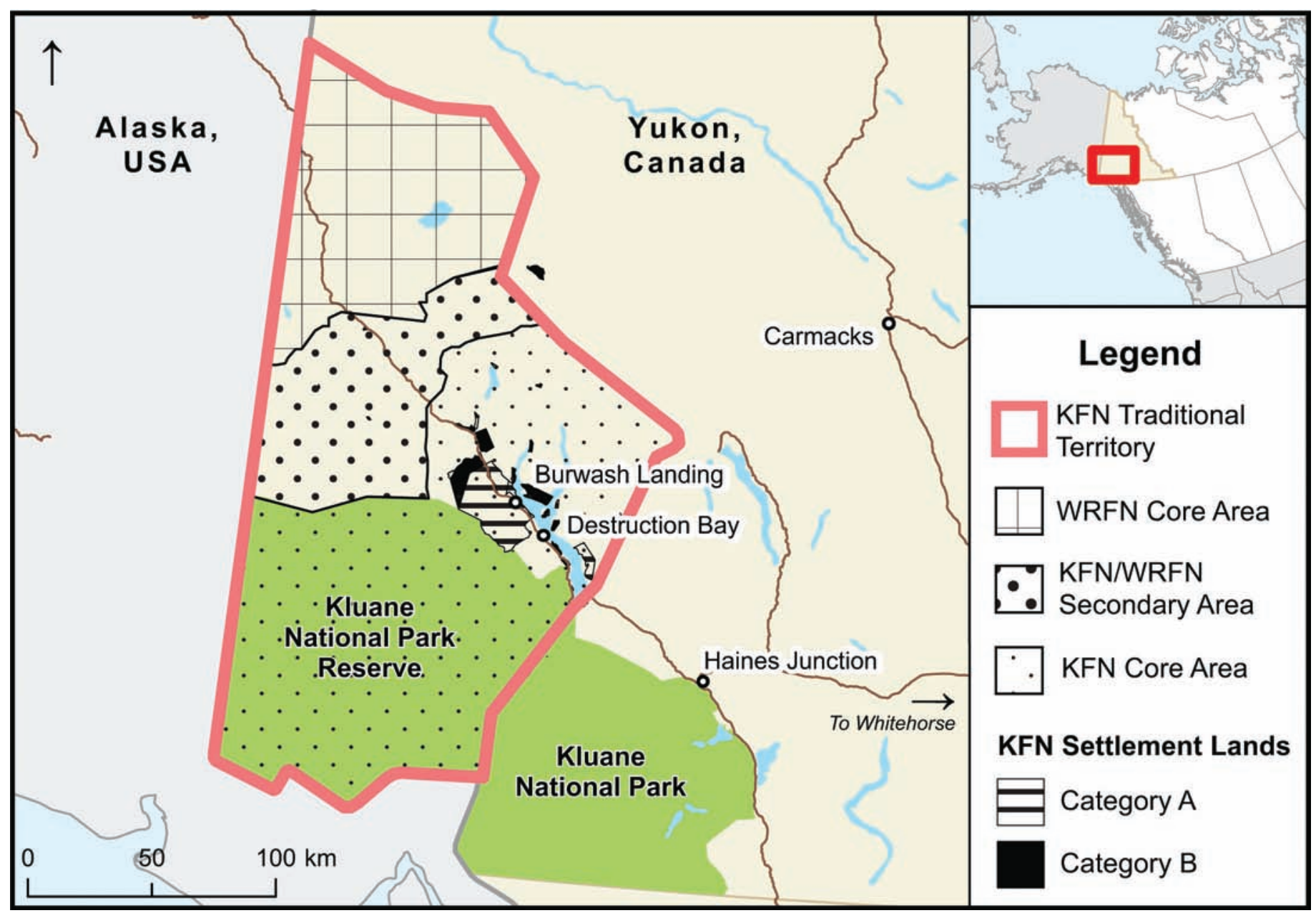

FIG. 1. Kluane First Nation traditional territory, showing Category A and B lands and the overlap with Kluane National Park and Reserve. KFN has exclusive jurisdiction in the KFN core area and shares jurisdiction with White River First Nation in the KFN/WRFN secondary area.

northwest of Whitehorse, Yukon, along the shores of Kluane Lake. KFN traditional territory (Fig. 1) is home to the Lù'àn Män Ku Dän, the Kluane Lake People, most of whom are descendants of Southern Tutchone speakers (KFN, 2019).

KFN is an ideal case study as its members continue to rely heavily on traditional food. At the same time, access to store-bought food remains limited, with the closest fully stocked grocery store located three hours away by car. KFN gained governance influence with the 2003 signing of its land claim agreement, which enabled province-like powers over Settlement Lands. Local government representatives and citizens now participate on various boards and councils that advise on issues affecting KFN traditional territory, including those related to the availability of and access to traditional food (Fred, 2008:3). The overlap between Kluane National Park and Reserve (KNPR) and KFN territory adds another governance relationship, thus allowing for the analysis of a broad variety of collaborative governance arrangements. Finally and importantly, food security is a policy priority for KFN. Its government has taken concrete policy steps to bolster food security, including the development of its own food security strategy, entitled Nourishing Our Future: An Adaptive Food Security Strategy to Ensure the Cultural and Physical Well-Being of the Kluane First Nation Against the Impacts of Climate Change in the Yukon. This document identifies key focal areas and associated actions for moving the community toward ongoing sustainability of the local food system (KFN, 2014).

\section{Collaboration with KFN}

This research was inspired by KFN's food security strategy, and aims to investigate opportunities for KFN (and other First Nations) to advance their traditional food security within the existing Yukon governance structure. In undertaking this participatory study, the researchers engaged with KFN throughout, initially by proposing the research to community leaders and requesting permission to undertake the study on KFN lands. KFN supported the research and agreed to participate, aiming to complement their food security strategy implementation process. A research agreement between the primary researcher (lead author) and KFN was subsequently developed and signed by both parties. The agreement specified KFN ownership 
TABLE 1. Interviewee affiliations and reference codes.

\begin{tabular}{|c|c|c|}
\hline \multirow[t]{3}{*}{ Kluane First Nation } & Staff Members: Lands, Resources and Heritage Department & KFN1, KFN2, KFN3 \\
\hline & KFN Chief (now former) & Mathieya Alatini \\
\hline & Citizen and former Land Claims Negotiator & KFN7 \\
\hline \multirow[t]{3}{*}{ Yukon Government } & Staff Members: Department of Energy, Mines and Resources, Mineral Resources Branch & YG1, YG2 \\
\hline & Staff members: Department of Energy, Mines and Resources, Oil and Gas Resources Branch & YG3 \\
\hline & Regional Biologist: Environment Yukon, Fish and Wildlife Branch & YG4 \\
\hline \multirow[t]{4}{*}{ Co-management Organizations } & Executive Director, Member: Dän Keyi Renewable Resources Council & $\mathrm{CM} 1, \mathrm{CM} 2$ \\
\hline & Director: Yukon Land Use Planning Council & CM3 \\
\hline & Staff Member: Yukon Fish and Wildlife Management Board & CM4 \\
\hline & Environmental Assessment Practitioner: familiar with Yukon Environmental and & CM5 \\
\hline
\end{tabular}

of all information collected in its traditional territory and allowed use of the material by the researchers for a limited time. KFN supported the application for a Yukon Research License, which was approved. Ethical approval was obtained from the University of Ottawa.

Throughout the fieldwork, writing, and review stages of this research, we engaged with KFN government representatives, seeking their comments and incorporating their feedback. To validate our findings, interviewees had the opportunity to review and provide feedback on the comments attributed to them, as well as contextual paragraphs that immediately preceded or followed their comments. A community report was provided to KFN leadership and made available to community members at a Research Summit in Burwash Landing, and KFN government staff co-authored and reviewed this manuscript.

As researchers, our perspectives are multifaceted. Cruickshank, of settler origins, worked as a political reporter for a Whitehorse newspaper before returning to graduate school and conducting the research described here. During her fieldwork period, she simultaneously worked with the Arctic Institute of Community-Based Research (AICBR) and KFN on a community-driven project to implement components of the KFN Food Security Strategy, which reinforced her understandings and relationships. Notten has strong research experience related to policy and governance, with a focus on poverty. Wesche has over a decade of experience working with northern First Nations communities, including Old Crow, Yukon, and has previous links with AICBR. Ballegooyen and Pope live and work in Burwash Landing, bringing their perspective as residents and KFN employees. Ballegooyen, a settler originally from Saskatchewan, works as Natural Resources Manager for KFN. While her primary focus is development assessment, she also facilitates research projects throughout the KFN Traditional Territory, and is dedicated to community building, believing that collaborative work and action will enable the transition to local food security. Pope, a Ta'an Kwäch'än Council citizen, has an intimate knowledge of KFN traditional territory through her work as the KFN Lands, Resources and Heritage Director, and as a Canadian
Ranger. She oversees the KFN wildlife-monitoring program, as well as the trapper's incentive program.

\section{Data Collection}

As indicated above, we analyzed the case study data in light of the theories and evidence from the co-management literature. For the remainder of this paper we therefore use the term "co-management" to refer to the various collaborative governance arrangements in which KFN is involved. These include formal and continuous arrangements such as participation in councils and boards, as well as related interactions (formal, informal, projectbased) between KFN staff and other co-management organizations (e.g., YG and Parks Canada), which were identified by interviewees as relevant to traditional food security.

Our analysis relied on data collected through semistructured interviews and through a review of publicly available resources published by First Nations and federal and territorial governments such as legislation, land claim agreements, and policy document. These offered information about the case study context in general, and more specifically, the formal governance context. Fieldwork for this research took place between June and August 2015, in Whitehorse (territorial capital) and in the smaller communities of Burwash Landing and Destruction Bay, in KFN traditional territory. Interviews were conducted with 23 political leaders, policy makers, and citizens with knowledge of specific co-management arrangements regarding lands and wildlife. Of these, 18 were analyzed in detail for this study (Table 1), while the remaining five provided important background context. Contributing participants included representatives from the following organizations: KFN (7), YG (5), Government of Canada (1), and co-management bodies (5), including the Land Use Planning Council and the Dän Keyi Renewable Resources Council. Interviewees were identified and contacted based largely on their employment position and level of involvement in wildlife management, land and resource management, or issues related to food security. Some interviewees were also identified through snowball sampling. 
We used an exploratory approach, where we sought to identify and better understand the ways in which co-management of land, wildlife, and resources may affect traditional food security, and the opportunities and challenges these regimes may present for KFN (and potentially other First Nations) as it exerts authority over the management of its traditional food system. To this end, interview questions were open-ended and varied somewhat depending on the position of the interviewee. Questions for interviewees who were either citizens or employees of KFN focused on how KFN contributes to land and wildlife management in its traditional territory and how food security is considered within those processes. They also addressed existing challenges regarding both KFN's participation in co-management and the consideration of food security in these processes, as well as opportunities for strengthening co-management in KFN traditional territory. Interviewees employed by YG were asked how their department considers First Nations food security in policy development and what opportunities First Nation governments have to influence policy development. Interviewees familiar with the Yukon environmental and socio-economic assessment process were asked how food security is considered in assessment processes, whether the organization proactively assesses impacts on food security, and how projects have been dealt with in the case of food security concerns. Interviewees involved in land-use planning in the territory were asked how food security is considered during those processes. A Parks Canada employee was also asked about the nature of the co-management of KNPR (see Appendix 1 online for interview questions). All participants reviewed and signed consent forms, indicating their preference for identification in research outputs, either by name, professional position, or organization and sector. Participant comments in the text are cited using the interviewee codes in Table 1.

\section{Data Analysis}

Interviews for this study were audio-recorded and later transcribed and coded using both inductive and deductive approaches in Dedoose qualitative data management software (Dedoose, 2017). We applied an inductive approach to a first round of open coding (Lune and Berg, 2017) using keywords to indicate when an excerpt was related to KFN context, food security, traditional foods, specific foods (e.g., moose, a significant source of meat for KFN), the entity being co-managed (e.g., lands, wildlife), the organization involved (YG, Parks Canada, KFN, other First Nations governments, or co-management bodies), the mentioning of specific concerns from the First Nation perspective (e.g., familiarity of YG employees with the Final Agreements, or public sharing of traditional knowledge), and the responses or additional context related to those concerns provided from YG or co-management organization interviews. Keywords were also used to code excerpts related to co-management benefits and successes, co-management challenges, and examples of noticeable differences in perspective (i.e., perspectives on the highway corridor).

We subsequently performed a second round of coding by concepts and themes using Berkes' (2007) seven dimensions of co-management as a framework (i.e., if a comment related to power sharing, trust building, or another element). Then we organized the excerpts coded by Berkes' seven dimensions according to the following questions: 1) How is co-management working? 2) What factors are important for a functioning co-management arrangement? 3) How can KFN's influence be strengthened to improve their ability to protect traditional food sources?

Three key themes emerged: trust and relationship building, information sharing, and power sharing. In the results and discussion section, we interpret these themes in light of the theories and evidence offered by the co-management literature, drawing particularly from publications that synthesize insights from a large body of case studies and those that focus on co-management in the North.

\section{CASE STUDY CONTEXT}

To understand how KFN influences the food security of its citizens through various co-management arrangements, this section offers a background on contextual aspects that co-management researchers identify as relevant: the formal institutions (rules) guiding co-management in northern Canada, the formal possibilities of using food security as a legitimate policy goal of co-management in northern Canada, the co-management arrangements in which KFN is engaged, and the food security context for KFN (Table 2).

\section{Formal Institutions Guiding Co-management in Northern Canada}

The formal governance system in northern Canada has changed significantly since the 1970 s, undergoing what Coates and Poelzer (2014:4) term a "revolution". In this time, both territorial and Indigenous governments gained new responsibilities through devolution and the establishment of self-government agreements and comprehensive, constitutionally protected land claim agreements (Pomeroy and Berkes, 1997; White, 2002; Coates and Poelzer, 2014). These agreements are complex and extensive. For this study in particular, they tend to involve the formal recognition of Indigenous ownership of a portion of the land covered by the claim in exchange for the release of territorial title (White, 2002). Importantly, Indigenous signatories tend to retain hunting rights, which are critical for traditional food procurement, throughout the territory covered by the claim (White, 2002). Indigenous governments also tend to gain formal representation on land and resource boards, which advise territorial governments on issues that may affect access to and the availability of traditional foods (White, 2002). These co-management boards typically 
serve in an advisory role, making recommendations to the relevant decision-maker on issues related to land and natural resources (White, 2008). In the Yukon, these decision-makers include YG or, in cases where Settlement Lands are involved, a self-governing First Nation. White (2008:74) argues that, despite a "lack (of) final decisionmaking authority...this advisory function is a far more potent prerogative than might be thought." In order for a government to reject or modify a board's recommendations, "ministers must expend their political resources (including laying out their objections in writing) and must do so quickly, or the land-claim board's recommendations come into effect by default" (White, 2008:74).

In Yukon, YG, self-governing First Nations, and the federal government share control of the territory. YG controls by far the largest area, but is required to consult Yukon First Nations (YFNs) regarding policy decisions that could impact their traditional territories. In 1993, YG, Government of Canada, and the Council of Yukon Indians (now the Council of Yukon First Nations) signed the Umbrella Final Agreement (UFA), setting the stage for the territory's 14 First Nations to finalize land claim and self-government agreements (Alcantara et al., 2012). Today, 11 of Yukon's 14 First Nations, including KFN, have concluded such agreements. The UFA also precipitated the creation of several co-management boards that include formal representation by YFNs (Alcantara et al., 2012) and established a formal process for YFNs and YG to develop regional land use plans (Council for Yukon Indians, Government of Canada and Yukon Government, 1993).

KFN's final and self-government agreements were signed in October 2003 (Fred, 2008). KFN Settlement Lands include $647.5 \mathrm{~km}^{2}$ of Category A land, which includes both surface and sub-surface rights, as well as $259 \mathrm{~km}^{2}$ of Category B land, which only includes surface rights (Fig. 1) (Fred, 2008). KFN is the decision-maker for its Settlement Lands, Parks Canada is the decision-maker for KNPR, and YG is the decision-maker for other lands in KFN traditional territory.

\section{Food Security as a Co-Management Goal}

Multiple chapters in the KFN Final Agreement include objectives that relate to traditional food system sustainability. Chapter 12 provides for a development assessment process that "protects and promotes the wellbeing of Yukon Indian People and of their communities and of other Yukon residents and the interests of other Canadians" and "protects and maintains environmental quality and ensures that Projects are undertaken consistent with the principles of Sustainable Development" (KFN et al., 2003:171). Chapter 14 addresses water management. Clause 14.8.1 indicates that "...a Yukon First Nation has the right to have Water which is on or flowing through or adjacent to its Settlement Lands remain substantially unaltered as to quantity, quality, and rate of flow, including seasonal rate of flow" (KFN et al., 2003:213); this has been used by KFN to protect fish spawning habitats from industrial development (Interviewee KFN3, 2019). Chapter 16 addresses fish and wildlife, outlining three objectives relevant to food security: "to ensure conservation in the management of all Fish and Wildlife resources and their habitats," "to preserve and enhance the culture, identity and values of Yukon Indian People," and "to ensure the equal participation of Yukon Indian People with other Yukon residents in Fish and Wildlife management processes and decisions" (KFN et al., 2003:231).

At the national level, Canada's constitution recognizes both a right to food and current and future treaty rights (Hanson, 2009; CCA, 2014). Various Supreme Court of Canada decisions have determined these rights to include among other things, the right to land, fishing, and hunting. These are rights that have direct implications for First Nations food security (Hanson, 2009).

\section{KFN Engagement in Co-management}

KFN is engaged in several formal and informal co-management arrangements involving various co-management partners, of which Parks Canada and YG are primary, because they have formal jurisdiction over the non-settlement parts of KFN traditional territory (Fig. 1) (Parks Canada, 2010; KFN et al., 2003).

The first group of co-management arrangements includes those institutionalized by the modern land claim agreements. These agreements require First Nations representation on any of the numerous technical advisory committees and management committees focused on wildlife. Those of particular relevance for First Nations food security include the Yukon Environmental and Socioeconomic Assessment Board (YESAB), the Yukon Fish and Wildlife Management Board, the Renewable Resources Councils, and the Yukon Land Use Planning Council. Below, we briefly discuss each.

The Yukon Environmental and Socio-economic Assessment Act (YESAA) applies to all Yukon lands; it addresses the requirements under Chapter 12 of the UFA for a development assessment process. The purpose of the Act is to ensure that environmental and socio-economic effects of projects are assessed before activities proceed. The arms-length YESAB conducts the assessments and guarantees opportunities for First Nations and public participation. The YESAB has to notify affected First Nations when a development project goes through the YESAA process (Interviewee CM5, 2015). While food security is not commonly considered as a value in itself through the assessment process, it is considered implicitly through consideration of how a project may affect wildlife populations (Interviewee CM5, 2015). One interviewee familiar with the assessment process indicated that food security would likely be more directly considered if it were raised more often as a concern through public or First Nations input (Interviewee CM5, 2015). 
TABLE 2. Key organizations and mandates.

\begin{tabular}{lll}
\hline \hline Category & Organization & Mandate \\
\hline First Nation Government & $\begin{array}{l}\text { Kluane First Nation, Lands, } \\
\text { Resources and Heritage Department }\end{array}$ & $\begin{array}{l}\text { The Lands, Resources and Heritage Department implements the KFN Final } \\
\text { Agreement relating to Settlement Lands and the use of natural resources and } \\
\text { heritage in the traditional territory. It aims to maintain land that can sustain } \\
\text { traditional uses and healthy fish and wildlife populations (KFN, 2019). }\end{array}$
\end{tabular}

\begin{tabular}{|c|c|c|}
\hline \multirow[t]{4}{*}{ Yukon Government } & $\begin{array}{l}\text { Department of Energy, } \\
\text { Mines and Resources, } \\
\text { Mineral Resources Branch }\end{array}$ & $\begin{array}{l}\text { The Mineral Resources Branch regulates and promotes mineral exploration and } \\
\text { development in the Yukon (EMR, 2018a). }\end{array}$ \\
\hline & $\begin{array}{l}\text { Department of Energy, } \\
\text { Mines and Resources, } \\
\text { Oil and Gas Resources Branch }\end{array}$ & $\begin{array}{l}\text { The Oil and Gas Resources Branch regulates and promotes development of the } \\
\text { territory's oil and gas resources (EMR, 2018b). }\end{array}$ \\
\hline & $\begin{array}{l}\text { Environment Yukon, } \\
\text { Fish and Wildlife Branch }\end{array}$ & $\begin{array}{l}\text { The Fish and Wildlife Branch is responsible for monitoring fish and wildlife } \\
\text { populations, habitat, wildlife, and harvest management (Environment Yukon, } \\
\text { 2017). }\end{array}$ \\
\hline & $\begin{array}{l}\text { Environment Yukon, } \\
\text { Environmental Programs Branch }\end{array}$ & $\begin{array}{l}\text { The Environmental Programs Branch analyzes potential environmental impacts, } \\
\text { monitors contaminated sites, remediates government-owned contaminated sites, } \\
\text { and issues permits for regulated activities (Environment Yukon, 2017). }\end{array}$ \\
\hline Government of Canada & $\begin{array}{l}\text { Parks Canada, } \\
\text { Kluane National Park and Reserve }\end{array}$ & $\begin{array}{l}\text { Parks Canada's mandate includes the protection of national parks and the } \\
\text { enhancement of public understanding to ensure future protection (Parks } \\
\text { Canada, 2018). }\end{array}$ \\
\hline \multirow[t]{4}{*}{ Co-management Organization } & Dän Keyi Renewable Resources Council & $\begin{array}{l}\text { Established through Yukon First Nation Final Agreements, RRCs provide local } \\
\text { input for managing fish and wildlife within the relevant traditional territory. The } \\
\text { Dän Keyi RRC provides opportunities for public consultation and makes non- } \\
\text { binding recommendations to Yukon Government, Kluane First Nation,the Yukon } \\
\text { Fish and Wildlife Management Board, and the Salmon Sub-Committee (Yukon } \\
\text { Government, 2018). }\end{array}$ \\
\hline & Land Use Planning Council & $\begin{array}{l}\text { The Land Use Planning Council makes recommendations to First Nations and } \\
\text { Yukon Government about land use planning as outlined in the Final Agreements } \\
\text { (Yukon Land Use Planning Council, 2018). }\end{array}$ \\
\hline & $\begin{array}{l}\text { Yukon Fish and Wildlife Management } \\
\text { Board }\end{array}$ & $\begin{array}{l}\text { The Yukon Fish and Wildlife Management Board is recognized in the UFA } \\
\text { as the primary instrument of fish and wildlife management in the Yukon. It } \\
\text { provides for public consultation and makes recommendations to the Minister, } \\
\text { First Nations, or the Federal Government based on a combination of technical, } \\
\text { traditional, and local knowledge (Yukon Fish and Wildlife Management Board, } \\
\text { 2019). }\end{array}$ \\
\hline & $\begin{array}{l}\text { Yukon Environmental and Socio-economic } \\
\text { Assessment Board }\end{array}$ & $\begin{array}{l}\text { The Yukon Environmental and Socio-economic Assessment Board assesses } \\
\text { proposed development projects as required by the Final Agreements (YESAB, } \\
\text { 2012). }\end{array}$ \\
\hline
\end{tabular}

The work of the Yukon Fish and Wildlife Management Board is similarly relevant in that it makes recommendations related to fish and wildlife management, which may affect the availability of traditional food sources. Required under the UFA, it is "the primary instrument for Fish and Wildlife Management in the Yukon" (Council for Yukon Indians et al., 1993:166). The Board, comprised of members nominated by both YG and the Council of Yukon First Nations, makes recommendations to decision-makers (YG, First Nations, or Federal Government) regarding fish and wildlife policies and legislation based on scientific and traditional knowledge (Yukon Fish and Wildlife Management Board, 2019).

The Renewable Resource Councils and local management bodies also advise the Yukon Fish and Wildlife Management Board and all levels of government on issues related to the management of land, fish, and wildlife within land claim areas, and thus may, through their work, have an effect on traditional food availability. The Dän Keyi Renewable Resources Council undertakes this function in KFN territory.

The Yukon Land Use Planning Council assists in the coordination of regional land use planning and is required to recognize and promote First Nations values. Due to its territorial scope, land use planning offers an opportunity to look at wildlife land management at a larger geographic scale and thereby identify areas critical to the protection of traditional food sources, regardless of whether these areas are subject to overlapping or intersecting governmental jurisdiction.

A second group of co-management arrangements, many of which have no formal institutional backing, constitute the direct relationships that KFN maintains with YG and Parks Canada. For instance, KFN maintains a working 
relationship with various YG departments, as well as its political arm. One interviewee credited KFN Chief Alatini's efforts to build relationships with $\mathrm{YG}$, which enables KFN employees to call up relevant ministers to address issues as they arise (Interviewee KFN1, 2015).

KFN members participate in the Kluane National Park Management Board, which makes recommendations to the Minister of Environment Canada (Interviewee KFN1, 2015), and also connects informally with KNPR employees. KFN representatives participate in activities in the National Park including wildlife population counts, and Parks Canada employees regularly attend KFN community meetings (Interviewee KFN1, 2015).

\section{Food Security Context for KFN}

KFN members continue to rely heavily on food from the land, particularly kanäy (moose, Alces alces), mäy (thinhorn sheep, Ovis dalli), mbet (lake trout, Salvelinus namaycush), lù (lake whitefish, Coregonus clupeaformis), and t'äwa (Arctic grayling, Thymallus arcticus) (KFN, 2014; Interviewee KFN3, 2018). While "...people out in the communities look at the land as a provider" (M.J. Johnson, 2015), KFN members face challenges in procuring sufficient, culturally preferred traditional food. Access to protected spaces is one challenge: “... access to [Kluane National] park is very limited. There are only a few roads that access the park and, of those few roads, even [fewer] ... go to areas where you may want to harvest things" (Interviewee PRK1, 2015).

Resource development represents another potential threat to KFN's food security. The exploration and development company, Nickel Creek Platinum Corporation (formerly Wellgreen Platinum Ltd.), has long expressed interest in developing an open-pit platinum mine on KFN traditional territory in an area that includes sensitive sheep habitat (Interviewee CM5, 2015).

Climate change is an additional stressor. For example, by stimulating the growth of trees and taller grasses, it is perceived to be affecting Arctic ground squirrel populations (Urocitellus parryii; commonly known as "gophers"), which thrive in open meadow habitat (Interviewee KFN2, 2015). Investigations of ground squirrel population declines in the region have highlighted factors such as increased predation risk due to both shrub encroachment in tundra and forest habitats, and low snowshoe hare populations in boreal forest habitat, which shifts predator pressure to ground squirrels (Hik et al., 2001; Donker and Krebs, 2012; Wheeler and Hik, 2014; Werner et al., 2015). In addition to these biophysical stressors, a shift away from certain traditional management practices is also perceived to affect the availability of wild food species, including ground squirrels.

Duke Meadow used to be an area where people went to harvest gophers all the time, and as part of that practice, there was some maintenance that took place. ... My grandmother would always pull the spruce trees and the willows ... to try to maintain it as a meadow so that the gophers would stay there. No one does that anymore, so you can see that it's really like growing in. So, eventually that meadow's gonna be gone, and the gophers will probably go with it because we're not maintaining that sort of same traditional way.

(Interviewee KFN7, 2015)

To protect its wild food sources, KFN is actively engaged in efforts to manage its traditional territory through the various co-management arrangements described earlier: "We are stewards of the land and we have a responsibility to manage wildlife and the ecosystem that supports the wildlife in a sustainable manner" (Alatini, 2015).

In 2014, KFN developed a local food security strategy in collaboration with the Arctic Institute of CommunityBased Research (KFN, 2014; Alatini, 2015; AICBR, 2017) in response to declining moose and caribou populations and in recognition of limited grocery store access. The threeyear project, partially funded by Health Canada, identified ways in which the community could adapt to climatic and lifestyle changes, supporting ongoing sustainability of the local food system (KFN, 2014).

[The food security strategy is] a useful document because it shares the community's views on certain topics, which gives the government something to refer to, especially when at times it can be difficult to get members out to community meetings.

(Interviewee KFN2, 2015)

A strategic plan not only signals a policy priority, but the act of identifying goals and actions can also help a government establish organizational focus and coordinate internal efforts (Notten and Laforest, 2016). While KFN's (2014) food security strategy does not directly address the government's participation on co-management boards, it details community-identified recommendations related to land, wildlife, and resource management. These include recommendations to:

- Promote and encourage conservation and protection of Kluane First Nation traditional territory.

- Continue monitoring key areas showing signs of climate change in the KFN territory, as well as the effects on traditional food resources in these areas. ...

- Encourage ancient methods of conservation for declining animal populations, such as moose, caribou, sheep and trout (i.e., no hunting in specific areas for a period of time to allow for replenishment of fish and wildlife populations)....

- Look for ways to have greater control over hunting and conservation in Kluane First Nation traditional territory.

KFN has direct influence over these policy areas at the scale of its Settlement Lands; however, at the larger scale of its traditional territory, these are the shared purview of 
KFN, Parks Canada, YG, and co-management bodies. Thus, in order to effectively act on these recommendations, $\mathrm{KFN}$ is likely to require the cooperation of its co-managers.

Finally, an advantage for KFN is that its policy goal of food security aligns very well with a key goal of Parks Canada, the lead player in co-managing a sizable part of KFN traditional territory:

Parks' objective is trying to enhance or trying to preserve ... wild food sources. So, there's no development in the park; there's all these protectionist types of legislation, as well as in the Final Agreements to protect those very things.

(Interviewee PRK1, 2015)

KFN is pretty lucky in the sense that there's a lot of protected areas in their traditional territory, with the Game Sanctuary and the Kluane National Park, and the Asi Keyi Territorial Sanctuary ... we'll still be able to practice subsistence hunting and, you know, berry harvesting and all that in those areas.

(Interviewee KFN7, 2015)

\section{RESULTS AND DISCUSSION}

This section analyzes the interview data through the lens of the co-management literature with the aim of understanding how KFN engagement in co-management contributes to food security for its citizens. The three key themes emerging from this research are trust and relationship building, information sharing, and power sharing. Within these three themes, the analysis also highlights the role of specific elements in the case study context - called situational factors in co-management research-whose presence is known to facilitate or hinder collaboration. Finally, the analysis also reveals some more tacit and practitioner-oriented insights as to how to make co-management work better in the context of Canada's North.

\section{Trust and Relationship Building}

The first theme emerging from the interviews was trust building as a necessary foundation, without which none of the expected benefits from collaboration could materialize. The co-management literature identifies trust and relationship building as a determinant for success in co-management, recognizing their importance for effective communication (Berkes, 2007). Likewise, participants in our study emphasized the importance of trust as a prelude to effective working relationships.

It is Mathieya's efforts; it's our (former) chief that's been able to get those relationships, to build it to the point that they respect Kluane First Nation enough to call and say, "Okay what is your issue and how can we help you?" ... If they can't, then they'll say, "We can't help you on that one" ... so we can understand it. So, it depends on the relationship that you build and the trust level that you have.

(Interviewee KFN1, 2015)

Similarly, trust building was also credited for the strength of KFN's relationship with Parks Canada compared to the relationship with YG: "I think maybe it's the trust thing, and you can actually see it happening; it's tangible.” (Interviewee KFN1, 2015)

Building trust is especially relevant and challenging when co-management partners have very different worldviews and when historic experiences and injustices have created mistrust, as is the case between Indigenous and non-Indigenous communities (Ostrom, 1990; Manseau et al., 2005; Berkes, 2007). KFN's relationship with Parks Canada illustrates how multiple concurrent approaches and activities can support the building and maintenance of trust between parties, and that this is key to establishing a functional working relationship, particularly when influenced by a challenging history.

Respondents from KFN and Parks Canada describe their current working relationship as very positive. KFN leaders meet regularly with Parks Canada representatives and are informed about activities taking place in the Park. KFN representatives participate regularly on the Kluane National Park Management Board, which makes recommendations to the federal Minister of Environment and Climate Change on Park management matters. KFN staff members also commonly take flights with Parks employees to conduct moose and sheep population counts (Interviewee KFN1, 2015).

However, the evolution of the relationship between KNPR and neighbouring First Nations, including KFN, has been long and arduous. With the establishment of the Kluane Game Sanctuary in 1943, KFN members and others were legally prevented from carrying out traditional hunting, trapping, and gathering activities within its borders. Removal from this portion of KFN traditional territory disrupted local knowledge systems, which were rooted in physical and spiritual connections with the land (Parks Canada, 2010). This had deeply negative effects on the community, causing food shortages and profoundly influencing hunting patterns and seasonal movements (Nadasdy, 2003). In 1976, the Sanctuary became Kluane National Park and Reserve under the federal Parks Act. While the Act allowed for the continuation of traditional harvesting activities, there was lack of clarity as to whether this stipulation applied, since local First Nation citizens had not harvested in the area for 30 years (Zanasi, 2005). As such, the effective displacement of KFN citizens from KNPR continued until 2003 when traditional harvesting rights were confirmed through the KFN Final Agreement. Impacts of this legacy persist (Nadasdy, 2003; Clark et al., 2014).

There was no trust between Parks Canada and either First Nation. ... Parks Canada had a very protectionist, 
exclusionary policy in the 70 s and the 80 s. ... The RCMP and Parks Canada had made arrests, or made efforts to remove people from the Park, and it wasn't [a situation that was] welcoming for traditional activities like hunting and fishing. ... It's a small community ... and people have long memories and ... they had some bad relations as a result. ... Just because a Final Agreement was signed and lawyers negotiated rights for First Nations within the park, this didn't make it suddenly okay for people to feel comfortable to re-enter the Park or do things. Even though they had full right and were aware of it, [they just weren't] comfortable being in the Park and being around the Parks Canada uniforms even.

(Interviewee PRK1, 2015)

In the period before land claim agreements were finalized, the establishment and management of KNPR was conducted with limited First Nation input despite significant subsistence and economic impacts on these populations. The 2003 ratification of the KFN Final Agreement resulted in the creation of the Dän Keyi Renewable Resources Council and membership on the Kluane National Park Management Board (joining Champagne and Aishihik First Nations, whose Final Agreement was ratified in 1993), re-initiating a level of influence over renewable resource management in KFN territory (Clark et al., 2014). Since the 1995 initiation of the co-management regime and KFN's participation since 2003, partners have been ensconced in a continuous process of learning how to undertake effective co-management in national parks, resulting in both successes and disappointments (Clark, 2009; Markel and Clark, 2012). Challenges, such as differing values and understandings of key concepts like respect for wildlife and appropriate methods and goals for research and management, have impacted trust and relationships among these partners (Clark et al., 2014).

Notwithstanding, KFN and Parks Canada have worked purposely to build their relationship over the intervening years. In 2000, a Parks Canada report explicitly recognized the important role of Indigenous peoples in maintaining ecological integrity within national parks (Parks Canada, 2000), reflecting a growing understanding of the interrelated nature of Indigenous-environment relationships. In response, a nationally funded, multiyear Healing Broken Connections project (2004-09) was initiated in the Kluane region, aiming "to reintegrate First Nation people back on the land within KNPR; and to determine how traditional knowledge might be used in the park management decision-making process" (Henry et al., 2008:5). The project, which included workshops, culture and science camps, trips into the park, and traditional knowledge collection (Parks Canada, 2010), appears to have achieved some success in improving cultural reintegration in KNPR (Henry et al., 2008). While the project has ended, Parks Canada continues to support such initiatives; for example, by hosting a summer 2015 fly-in gathering with $60 \mathrm{KFN}$ citizens at Bighorn, a culturally significant area in the Park. These activities have positively influenced the relationship from both sides: "There was a bad attitude way back when, but I think Parks has really, really tried to change that around. Right now, we have a pretty good relationship with them" (Interviewee KFN1, 2015). It has also helped to address the fear and hesitancy among some KFN citizens who still remember the years of exclusion from the Park:

If a kid is harvesting a sheep or gophers or whatever in the Kluane National Park with a Park warden, they're not going to have that same kind of fear that, you know, their grandmother has.

(Interviewee KFN7, 2015)

A situational factor that supports contemporary relationships between co-management partners (Ostrom, 1990) is the fact that KFN and Parks Canada have overlapping interests as both users and stewards of the land. Interviewees noted that overlapping mandates regarding wildlife management make the relationship inherently less confrontational: Parks Canada is not required to address questions of resource development in KNPR because the area is protected (Interviewee KFN7, 2015). By contrast, the relationship between KFN and YG may have more points of tension as the goals of conservation, traditional food availability, and access are more likely to compete with those of other land uses and users (Alatini, 2015; Interviewee KFN1, 2015; Interviewee KFN3, 2015; Interviewee YG1, 2015).

Nonetheless, KFN's current working relationships with different arms of YG are relatively constructive. Our data indicate that the leadership skills of KFN's (then) Chief Alatini had an important influence. Despite the fact that her politics did not match those of the government at the time, Alatini took a personal approach to building relationships. "I actually have a conversation with the premier. If I have a problem, I will call him and say, 'Look, I have a problem.' I'm not a Conservative, but I can talk to Conservatives" (Alatini, 2015). The quality of leadership is a long recognized situational factor in co-management research (Ostrom, 1990).

Good intentions are important for trust building on both sides, and these appear to be prevalent among many $\mathrm{YG}$ employees. "For the most part, I just see a ton of people that really take that concern about protection of people and the environment quite seriously ... every day" (Interviewee YG3, 2015). Interviewees further indicated that YG departments are typically responsive when KFN brings concerns to their attention (Interviewee KFN1, 2015) and make efforts to build relationships with First Nations. For example, YG's five regional biologists are tasked with serving as liaisons between Environment Yukon and First Nations via communication and relationship building with First Nations in their region (Interviewee YG4, 2016).

Meeting outside the office environment is particularly effective for building trust and relationships. For example, the Kluane area regional biologist has attended KFN 
community events and participated in community life outside of official government business, which has been well received (Interviewee CM1, 2015). One participant from a co-management body explained that meeting on the land can help increase awareness and build understanding of co-management within communities:

It can't all happen in an office setting. ... On the land, most of the successful moments where cooperative management has really shone have been out on the actual landscape when you can bring these people together and mingle. ... We're familiar with cooperative management, but the local people aren't because if you're not invited to it, if you don't actively get to be part of what's going on, then you don't even really understand what is cooperative management. I think that's a really important part, but it takes time. And again when your capacity is limited as Kluane First Nation's often is and you're just run-stretched thin, you know, you can't even breathe-you're probably not putting a lot of priority behind ... 'Yeah, let's do a day camp with Yukon Government, ... let's get our Elders and the government people together.' It's kind of not really a priority, but it's actually the most effective thing that you could do.

(Interviewee CM1, 2015)

Despite the generally positive governance environment, opportunities exist to further improve the KFN-YG relationship. While some key employees have held their position for multiple years and developed appropriate skills and experience, the significant rate of YG employee turnover and limited levels of training regarding First Nations issues and legislation were identified by some as particularly challenging. One participant said it would be helpful if new employees went through training about YFNs and the Final Agreements:

I don't think the players there stick around long enough to really care. Their turnover is so high, it's rare that you get to work with one person for very many years there. ... I think it would really help if Yukon Government personnel all went through that First Nations 101 training and realized what First Nations are all about, and if they had an idea about what those Final Agreements were about.

(Interviewee KFN1, 2015)

Armitage et al. (2009) highlight the importance of strong connections to place, building stakeholder capacities, and establishing long-term commitments as important drivers in building and sustaining successful co-management arrangements. Our research confirms that building relationships and trust is a dynamic process consisting of repeated interactions between co-management partners (Berkes, 2007). A particularly practical insight offered by study participants is that building trust between First
Nations and other co-management partners happens through regular interactions between partners on location in First Nations communities and on their lands. In a relatively small jurisdiction in the Yukon, where residents have more direct access to politicians, professional relationships are often inherently more personal, and individuals can hold significant sway. This also means that formal business transpires not only in formal venues, but also via informal connections and discussions. Encouraging these interactions on location in First Nations communities may help to establish the critical foundations for meaningful professional relationships. As the foundation for effective co-management, these relationships are vital to the successful implementation of some of the recommendations made in KFN's food security strategy, as some, including those relating to the conservation of KFN's traditional territory and traditional food sources, fall under the shared purview of KFN, YG, and Parks Canada.

\section{Information Sharing}

The second theme that emerged from our analysis is the role of information sharing in improving resource management. Common-pool resources can be more effectively managed when co-management partners combine their financial, human, and other resources to work toward joint goals. This involves creating linkages among different types and levels of organization (Carlsson and Berkes, 2005). In terms of First Nations food security, benefits could arise from sharing different types of knowledge among co-management partners, such as traditional harvesting locations, wildlife population health status, and details about potential development. Indeed, improved sharing of relevant information and data between the co-managers of KFN's traditional territory could help satisfy recommendations in KFN's food security strategy. For instance, the recommendation to promote "ancient methods of conservation for declining animal populations" (KFN, 2014:21) could be more easily satisfied if co-management partners shared the tasks of collecting and analyzing data on wildlife population trends and potential threats to wildlife. Our findings suggest that while there is an understanding of the potential benefits that arise as a result of information sharing and that this process already occurs to some degree, barriers to furthering this type of exchange remain.

Trust is critical for fostering willingness among partners to share potentially sensitive information and to communicate more openly (Berkes, 2007). From KFN's perspective, sharing traditional harvesting information with YG is a sensitive issue.

I think there's a real reluctance sometimes on the behalf of the First Nation to provide traditional knowledge without knowing how that knowledge is going to be used ... and that was always a big issue for us when we were collecting information back in the days, you know, 
through land negotiating. People were really reluctant to provide a lot of information to government about areas that were important to them ... they wanted to sort of keep them safe. So, I think that's another reason why KFN might not necessarily be comfortable sharing or may not even have that information 'cause people are concerned about sharing it.

(Interviewee KFN7, 2015)

I think it's a trust thing right? ... you just got to sort of continue to build it. And governments have got to take First Nations' word on a few things and First Nations need to find some comfort in being able to provide a little bit more information in certain areas.

(Interviewee KFN7, 2015)

YG participants recognized these First Nations' concerns about sharing sensitive traditional knowledge and acknowledged the need to both be careful with knowledge that is shared and limit access to it (Interviewee YG4, 2015; Interviewee YG1, 2015). One interviewee said, "There's some sensitivities for First Nation people about sharing that data, so it's something that we're sensitive to and [we are] careful with that data of course" (Interviewee YG4, 2015).

Within YG's Mining Branch, there have also been recent discussions about the need to develop a process or policy, similar to that of YESAB, to restrict public assess to traditional knowledge, in an effort to address some First Nations' concerns (Interviewee YG1, 2015).

Alongside these trust-related concerns regarding adequate protection of traditional knowledge, KFN participants identified concerns about the appropriate use of traditional knowledge when it is shared (Interviewee YG1, 2015; Interviewee KFN7, 2015). While YESAB has a process in place to restrict public access to sensitive traditional knowledge that First Nations submit during project assessments (Department of Justice, 2003; YESAB, 2005), one KFN citizen noted: “... the YESAB process has never been able to take traditional knowledge and ways of life and worldviews with the same understanding and impact as Western science" (M.J. Johnson, 2015). Our interviewees indicated that there remains a need to deepen the understanding between First Nations and Western cultures. Clearly, where partners from different cultures are engaged, co-management must involve "a process of learning to respect differences;" otherwise, it will fail (Berkes, 2007:26).

At the same time, both KFN and YG interviewees highlighted the need for better information sharing between their governments. From KFN's perspective, it would be beneficial if YG provided wildlife harvesting data more readily and in more detail. Without accurate population data that demonstrates a need for conservation, it can be difficult for KFN government to ask its citizens to curb their subsistence hunt (Interviewee KFN3, 2015). From YG's perspective, there was recognition that if First Nations felt comfortable sharing key information such as locations used for traditional practices, it could allow the government to better protect those key areas from resource development (Interviewee YG1, 2015).

While there is a structure in place for Yukon First Nation and the general public to participate in land use and wildlife management decisions, interviewees from KFN, YG, and co-management bodies raised concerns about information gaps. As discussed above, some gaps arise because co-management partners do not want to share existing knowledge. Other gaps arise because relevant data are not collected; interviewees from KFN and YG both referred to limited resources and alternate priorities as the main reason for such gaps. Gaps in both traditional and scientific knowledge remain.

One of the challenges we run into ... is the lack of good baseline information and the lack of documented traditional knowledge. So, in areas where there's maybe activity going on, there's often no documented traditional knowledge on the use of the land.

(Interviewee YG2, 2015)

There is a need for continued documentation of knowledge as ecosystems and land use practices change. For instance, new technologies may mean that community members no longer hunt in large groups, reducing the level of shared knowledge about certain areas, even if they are used frequently (Interviewee KFN7, 2015). This challenge is exacerbated by limited human and financial resources in many small First Nations, which limit the amount of information they can collect and share. For example, one KFN employee is responsible for commenting on all YESAB reviews, so collecting traditional knowledge would represent a significant additional effort.

Interviewees also underscored the importance of collecting more scientific data, highlighting the need for better information regarding wildlife trends and population health (Interviewee CM3, 2015; Interviewee CM5, 2015; Interviewee YG2, 2015). However, resource limitations require $\mathrm{YG}$ to prioritize its data collection based on a number of criteria, including conservation and sustainability concerns, potential development, time since last population survey, and areas where there is mutual buy-in from governments and harvest groups (Interviewee YG4, 2015).

One thing we try to do is focus our survey efforts in areas where we have some general proactive agreement from all the harvesters [and] all the governments [so] that there will be an effort to do something about those numbers. So, if we find out that harvest is unsustainable ... then if we do that survey, we really hope that subsistence harvesters will be part of the effort to reduce harvest. ... We do try to prioritize areas ... [where] we think we can make a difference.

(Interviewee YG4, 2015) 
To illustrate, in response to KFN's stated interest and offer of financial contribution, YG agreed to undertake a survey to collect moose population data in 2014. Collecting this type of wildlife data is akin to managing a common pool resource in that the cost is borne by individual users or entities, while the outcomes of such activities benefit all users; this can incentivize free riding on the efforts of others (Ostrom, 1991). Our case study shows that co-financing may sometimes help overcome the free rider problem because it shows commitment, which in turn can help create a coalition among the partners who benefit most from the investment (Olson, 2000). However, in co-management regimes such as the Yukon where one or two co-management partners (e.g., YG, Parks Canada) have greater resources and capacities than their smaller First Nations government partners, undue onus should not be placed on the partner with fewer resources to finance activities that will advance their food security. In the case of the moose survey, the decision to co-finance has not furthered community buy-in or coalition building between co-managers (Interviewee KFN3, 2019). Funds that could have been directed to other initiatives were diverted from KFN's conservation fund, which is financed through a sheep tag auction. KFN has yet to receive the results of the survey, which was completed in 2014. Furthermore, opportunities for comparing results between the 2014 survey and previous surveys are expected to be limited due to a change in methodology (Interviewee KFN3, 2019). Thus, while co-financing may overcome some challenges in co-managing shared resources, this practice may present unique challenges of its own.

\section{Power Sharing}

The third theme that emerged from the interviews is the degree of control that KFN is able to exercise over decisions affecting the sustained availability of and access to traditional food sources. KFN's food security strategy alludes to concerns around KFN's limited decisionmaking power over its traditional territory by including a recommendation to "look for ways to have greater control over hunting and conservation in Kluane First Nation traditional territory" (KFN, 2014:21). A key insight from the literature indicates that while co-management involves multiple user groups in decision-making processes, the actual sharing of decision power "is the result, and not the starting point, of [a co-management] process" (Carlsson and Berkes, 2005:65). Having formal institutions that codify rights and responsibilities is furthermore helpful but not a guarantee that power sharing will occur through co-management (Berkes, 2007; Armitage et al., 2009). This is because KFN is only one of several resource users with an advisory role in decisions affecting its traditional territory through the co-management arrangements that emerged from its land claim agreement. Under this legislative framework, YG, which has a greater governance capacity than the smaller self-governing First Nations, remains the most powerful co-management partner in the Yukon. Moreover, even though First Nations have the option to use the federal judiciary system to enforce constitutional rights in cases of disagreement, such processes have very high costs in terms of resources and duration and may thus not be pursued despite promising jurisprudence (Desmarais and Wittman, 2014).

Our research corroborates these insights from co-management research. KFN has been able to exercise influence over resource management decisions relevant to its traditional territory, but its power is limited. Moreover, its influence on decision-making has emerged over time and involved processes of learning, problem solving, and local institution building (Berkes, 2007; Armitage et al., 2009).

Our interviews yielded quite a few cases exemplifying the growing problem-solving capacity and learning by co-managers. For instance, the declining moose population has been a concern since the 1990s, but only when KFN and YG identified and seized the opportunity to co-finance did periodic joint moose population counts outside KNPR became feasible. Another example is the collaboration between YG, Parks Canada, and KFN to develop a Kluane/Duke River Moose Harvest Management Strategy to address overharvesting (Parks Canada, Dän Keyi Renewable Resources Council, Kluane First Nation, Yukon Environment, 2014). One YG official indicated that the process has, "had some really good successes in terms of relationship-building, but it's also had some challenges as well, and that's something we're kind of working out right now" (Interviewee YG4, 2015).

Similarly, YG, YFNs, and co-management bodies such as the Yukon Water Board are working jointly to review the territory's mine licensing process, with a view to better incorporating traditional knowledge (Interviewee YG1, 2015). Discussions are slated to include planning around critical wildlife habitat and cultural areas. More specifically, the aim is to create new processes to improve the information that YG has access to regarding areas that are highly valued by First Nations, including those important for plants, fish, and wildlife, and by extension, food security (Interviewee YG1, 2015).

Our findings further indicate that building local institutions has helped KFN to exert more influence over activities on its lands, and continued investment in these processes may enable KFN to more fully exercise the power that was devolved to the local level through its land claim agreement. For instance, KFN has developed a land use plan, which may provide political strength in situations where it is pushing for further protections outside its Settlement Lands. Additionally, in an effort to address illegal hunting, KFN passed a Trespass Act (Interviewee KFN1, 2019), as a lack of local rules made it easy for outsiders to harvest from KFN's Settlement Lands:

The Duke Meadow is a very good hunting area for moose. It is Category A land. We have asked our own citizens not to hunt there for the past couple of years 
because the moose numbers are declining, and our citizens will drive past and they will see a non-First Nations person hunting exactly where they have been told or requested not to hunt.

(Interviewee KFN1, 2015)

However, as an example of the arduous, bureaucratic nature of institution building, KFN must first enact justice laws to enable enforcement of its Trespass Act (Interviewee KFN3, 2019).

Interviewees also identified clear institutional challenges that limit KFN's power to ensure the sustainability of traditional food sources in its traditional territory. First, the land claim agreement only gives advisory powers to First Nations outside their Settlement Lands, and second, it does not formally prioritize First Nations' needs. Changing either of these norms requires a change in formal institutions, something that is not likely to occur in the foreseeable future. In the words of KFN's former land claims negotiator,

... there are a lot of fora and opportunities for First Nations to ... influence decision-making, and I think ... for the most part it works, but at the end of the day can KFN necessarily stop something from happening? ... It depends on the issue, right? I mean if it is on Settlement Land, sure. But ... when it comes to lands and resources, fish and wildlife, those types of things, Yukon has the decision-making authority. And ... there are lots of ways for KFN to influence that ... but they ... do not control it.

(Interviewee KFN7, 2015)

Interviewees raised concerns about KFN's lack of influence over traplines, hunting quotas for outfitters in the region, and commercial fishing licenses. Of particular concern during the summer of 2015 was YG's decision to remove the corridor that restricted hunting for one kilometer on either side of the Alaska Highway. The corridor was initially meant to increase safety and protect wildlife from unsustainable hunting pressures during highway construction (Interviewee YG4, 2018). However, a regional biologist explained that "Yukon Government has been moving away from the use of highway corridors for conservation for many years. They are not considered an effective or fair tool because they are generally only enforceable for non-subsistence harvesters" (Interviewee YG4, 2018). While the Dän Keyi Renewable Resources Council, Yukon Fish and Wildlife Management Board, and YG argued that the corridor was not an effective approach for protecting moose (Interviewee YG4, 2018), KFN felt that removing it would only increase hunting pressure on the already declining population. "[Now] you don't even have to get off the highway; you just have to get out of your truck and stand in the ditch" (Interviewee KFN1, 2015).

Similar power dynamics emerged in a contrasting case along the Dempster Highway where the Tetlit Gwich'in
Renewable Resources Council, on advice from community Elders, hunters, and leaders in Fort MacPherson, proposed a temporary closure of caribou hunting from the highway based on traditional knowledge assertions that the herd leaders should not be disturbed (Padilla and Kofinas, 2014). In 1995, a "let the leaders pass" regulation was endorsed by the Porcupine Caribou Management Board and implemented by YG. In 2007, the regulation was contested by a Tr'ondëk Hwëch'in (Dawson) First Nation member, who claimed insufficient consultation and lack of alignment with his Nation's traditional knowledge. The Yukon Territory Minister of Environment responded by shifting to a "voluntary compliance" approach due to lack of consensus among affected parties (Padilla and Kofinas, 2014). As such, in both the Alaska Highway and Dempster Highway cases, traditional knowledge was both recognized and valued by the co-management boards and influenced both discussions and decision making. However, ultimately, it was deemed neither sufficiently robust nor applicable beyond the local context, leading YG to exert its ultimate power over First Nations territory.

While each co-management party has certain levels of influence, situational factors such as the political and economic climate also drive the recommendations of co-management boards (Nadasdy, 2007). For instance, one environmental assessor noted that YESAB members and staff are conscious that the assessment board operates within a specific political and economic context, and the assessor makes recommendations that are perceived to be acceptable within that context:

In a political climate that values resource development, there would have to be significant adverse effectsfor instance adverse effects to caribou to the point of no recovery-for YESAB to recommend that Yukon Government reject a project.

(Interviewee CM5, 2015)

One opportunity to increase First Nations' influence involves framing their advice on land use as a food security issue. An environmental assessment practitioner indicated that the YESAB would be better positioned to consider the impact of development projects on KFN's traditional foods if the First Nation more frequently raised the issue in its comments (Interviewee CM5, 2015). Moreover, by framing its input using the political language of food security, KFN could potentially shift the conversation to highlight food security, access to food, and right to food in contrast to development. As Desmarais and Wittman (2014) point out, First Nations have won important court cases by underscoring their rights to accessing and protecting traditional foods. Emphasizing constitutional rights in addition to those derived from land claim agreements could help shift the power balance within co-management arrangements. 
At the end of the day there should be few things that would ever take priority over, you know, things like our subsistence rights, and that is pretty clear in those treaties.

(Interviewee KFN7, 2015)

\section{Limitations}

There were a number of primarily methodological limitations to this study. Interviews were broad, precluding in-depth examination of specific instances or examples. Furthermore, while some YG and co-management agency participants had knowledge of co-management with Kluane First Nation specifically, others spoke more broadly about territorial policies around consultation and departmental efforts to improve relationships. Thus, insights into KFNspecific on-the-ground workings of co-management were limited from these perspectives. In terms of scope, the relationship of focus was limited to KFN, to the exclusion of existing and proposed co-management relationships with Champagne and Aishihik First Nations and White River First Nation (WRFN) (which has yet to settle its land claim), whose territories overlap with KFN.

\section{CONCLUSION}

Our research shows that the theories and empirical evidence from the rich co-management literature improve our understanding of how First Nations food security can be supported through the co-management of land and wildlife in northern Canada. Many concepts and theories of co-management emerged as relevant in this case study (italicized below), and together they advance our understanding of how co-management can both help and hinder First Nations communities in maintaining sustained availability of and access to traditional foods within the current governance regime.

Trust building is the foundation without which none of the other co-management dimensions can materialize. The history of conflict among natural resource users and managers from different cultures makes building trust an essential activity, especially (though not exclusively) in the early stages of co-management. As trust develops, other co-management dimensions such as social learning, institution building, and problem solving also develop. KFN and the other resource users and managers, are learning how to use and shape the still relatively new decision-making space formed by the land claim agreements. KFN employees are building networks around and beyond formal co-management arrangements and are able to mobilize them to address issues affecting the availability of and access to traditional foods. As a selfgoverning First Nation, KFN is building institutions locally to fill regulatory gaps following the settlement of its land claim agreement, allowing it to exercise more control over its Settlement Lands. KFN is problem solving with other co-management partners regarding issues that affect its traditional territory, such as through joint participation and financing of moose population counts as a means to gain traction regarding specific wildlife concerns. The sharing of information and communication more broadly are key means through which social learning, institution building, and problem solving occur. The consequence of these efforts is that KFN can exercise power over decisions that affect the sustained availability of and access to traditional foods, which are an important contributor to the food security of community members.

Our findings indicate that the co-management arrangements in which KFN participates are slowly maturing, with some partnerships having reached higher levels of collaboration (e.g., Parks Canada versus YESAB and various parts of $Y G)$. A crucial factor explaining these differences is the degree to which the different partners trust and understand each other. There is a need for further trust building between First Nations and various territorial government players. Without such efforts, further opportunities for sharing information will not materialize, nor will it be attractive for co-management partners to invest their own limited resources to collect new information that could improve resource management. Nonetheless, various known contextual factors also play a role. One reason for the differences in relationship maturation is that the goals of First Nations and territorial governments are more likely to diverge, thereby making co-management relations inherently more conflictual. The leadership exercised by certain individual champions appears to be another relevant contextual factor (Ostrom 1990; Armitage et al., 2009; Clark and Slocombe, 2011), one that can contribute positively to relationship building and the exercising of First Nations influence.

There are a number of opportunities for building on this research. A multiple case study design would be useful in identifying and comparing similarities and differences in the experiences of various YFNs that participate in land use and wildlife management. Likewise, further research could usefully test the strength of our conclusions, including the degree to which the framing of food security as a co-management goal may influence the perspectives and participation of co-managers in land and wildlife decision making.

In sum, a key contribution of this research is that it is the first to apply the knowledge from the co-management literature to a case study focusing on the relationship between co-management and food security in northern First Nation communities. This new avenue for research offers many analytical tools that could help make policy and governance a positive rather than a negative driver of food security (Loring and Gerlach, 2015). Another key contribution of this research, relevant for both practitioners and co-management scholars, is that First Nations in northern Canada may increase their influence on resource management decisions by framing resource use issues through the lens of food security, thereby making a tighter connection between 
resource use, traditional foods, and constitutional rights. Building local institutions and the formulation of local resource use strategies can further help First Nations to gain more control over food security. Yet, while showing the potential for increased decision-making power for First Nations communities, there are clear limits to its expansion within the current institutional and cultural context.

\section{ACKNOWLEDGEMENTS}

We thank all of the participants who took part in this research, particularly members of KFN who supported this project. We also thank Melissa Marschke, Sarah Macritchie, Jessica Lim, Vinay Rajdev, and two anonymous reviewers for their comments, as well as Sarah Simpkin for producing Figure 1. We appreciate the funding and logistical support provided by the Students for Canada's North program at the University of Ottawa and AICBR in Whitehorse, which made this work feasible. The authors are solely responsible for the analyses and conclusions.

\section{REFERENCES}

AICBR (Arctic Institute of Community-Based Research). 2017. About us. https://www.aicbr.ca/about-us

Alcantara, C., Cameron, K., and Kennedy, S. 2012. Assessing devolution in the Canadian North: A case study of the Yukon Territory. Arctic 65(3):328-338. https://doi.org/10.14430/arctic4220

Armitage, D.R., Plummer, R., Berkes, F., Arthur, R.I., Charles, A.T., Davidson-Hunt, I.J., Diduck, A.P., et al. 2009. Adaptive co-management for social-ecological complexity. Frontiers in Ecology and the Environment 7(2):95-102. https://doi.org/10.1890/070089

Berkes, F. 2007. Adaptive co-management and complexity: Exploring the many faces of co-management. In: Armitage, D., Berkes, F., and Doubleday, N., eds. Adaptive co-management: Collaboration, learning, and multi-level governance. Vancouver: UBC Press. 19-37.

. 2009. Evolution of co-management: Role of knowledge generation, bridging organizations and social learning. Journal of Environmental Management 90(5):1692 - 1702.

https://doi.org/10.1016/j.jenvman.2008.12.001

Berkes, F., George, P., and Preston, R.J. 1991. Co-management: The evolution in theory and practice of the joint administration of living resources. Alternatives 18(2):12-18.

Carlsson, L., and Berkes, F. 2005. Co-management: Concepts and methodological implications. Journal of Environmental Management 75(1):65-76. https://doi.org/10.1016/j.jenvman.2004.11.008
CCA (Council of Canadian Academies). 2014. Aboriginal food security in northern Canada: An assessment of the state of knowledge. The Expert Panel on the State of Knowledge of Food Security in Northern Canada. Ottawa: CCA.

https:/cca-reports.ca/reports/aboriginal-food-security-innorthern-canada-an-assessment-of-the-state-of-knowledge/

Clark, D. 2009. Societal dynamics in grizzly bear conservation: Vulnerabilities of the ecosystem-based management approach. Park Science 26(1):50-53.

Clark, D., and Joe-Strack, J. 2017. Keeping the "co" in the comanagement of northern resources. Northern Public Affairs 5(1):71-74.

http://www.northernpublicaffairs.ca/index/magazine/volume5-issue-1/

Clark, D.A., and Slocombe, S. 2011. Adaptive co-management and grizzly bear-human conflicts in two northern Canadian Aboriginal communities. Human Ecology 39(5):627-640. https://doi.org/10.1007/s10745-011-9423-x

Clark, D., Workman, L., and Slocombe, D.S. 2014. Sciencebased grizzly bear conservation in a co-management environment: The Kluane region case, Yukon. In: Clark, S.G., and Rutherford, M.B., eds. Large carnivore conservation: Integrating science and policy in the North American West. Chicago: The University of Chicago Press. 108-139.

Coates, K., and Poelzer, G. 2014. An unfinished nation: Completing the devolution revolution in Canada's North. Ottawa: Macdonald-Laurier Institute.

https://www.macdonaldlaurier.ca/files/pdf/MLIArctic DevolutionPaper04-14-webready.pdf

Council for Yukon Indians, Government of Canada and Yukon Government. 1993. Umbrella Final Agreement between the Government of Canada, the Council for Yukon Indians and the Government of the Yukon.

https://www.rcaanc-cirnac.gc.ca/eng/1297278586814/1542811 130481

Dedoose (version 7). 2017. Web application for managing, analyzing, and presenting qualitative and mixed method research data. Los Angeles, California: SocioCultural Research Consultants LLC.

www.dedoose.com

Department of Justice. 2003. Yukon Environmental and Socio-economic Assessment Act (S.C. 2003, c. 7). Ottawa: Government of Canada.

http://laws-lois.justice.gc.ca/eng/acts/Y-2.2/

Desmarais, A.A., and Wittman, H. 2014. Farmers, foodies and First Nations: Getting to food sovereignty in Canada. Journal of Peasant Studies 41(6):1153-1173. https://doi.org/10.1080/03066150.2013.876623

Donker, S.A., and Krebs, C.J. 2012. Evidence for source-sink dynamics in a regional population of Arctic ground squirrels (Urocitellus parryii plesius). Wildlife Research 39(2):163-170. https://doi.org/10.1071/WR11167

EMR (Energy, Mines and Resources). 2018a. Minerals. Whitehorse: EMR, Yukon Government. http://www.emr.gov.yk.ca/mining/ 
2018b. Oil and gas resources. Whitehorse: EMR, Yukon Government.

http://www.emr.gov.yk.ca/oilandgas/index.html

Environment Yukon. 2017. About Environment Yukon.

http://www.env.gov.yk.ca/environment-you/aboutenvironment-yukon.php\#fw

Evans, L., Cherrett, N., and Pemsl, D. 2011. Assessing the impact of fisheries co-management interventions in developing countries: A meta-analysis. Journal of Environmental Management 92(8):1938-1949.

https://doi.org/10.1016/j.jenvman.2011.03.010

FAO (Food and Agriculture Organization of the United Nations). 1996. Rome declaration on world food security. World Food Summit, 13 - 17 November 1996, Rome, Italy. www.fao.org/docrep/003/w3613e/w3613e00.htm

- 2015. The state of food insecurity in the world 2015. Meeting the 2015 international hunger targets: Taking stock of uneven progress. Rome: FAO.

http://www.fao.org/3/a-i4646e.pdf

Feeny, D., Berkes, F., McCay, B.J., and Acheson, J.M. 1990. The tragedy of the commons: Twenty-two years later. Human Ecology 18(1):1-19.

https://doi.org/10.1007/BF00889070

Fred, J. 2008. First Nation community profiles: Kluane First Nation - Communities of Burwash Landing and Destruction Bay. Yukon Government.

http://www.eco.gov.yk.ca/pdf/FN_Com_Profile_KFN_LH_ Ed.pdf

Hanson, E. 2009. Aboriginal rights. Vancouver: First Nations \& Indigenous Studies, University of British Columbia. http://indigenousfoundations.arts.ubc.ca/aboriginal_rights/

Henry, D., Landry, A., Elliot, T., Gorecki, L., Gates, M., and Chow, C. 2008. State of the park report: Kluane National Park and Reserve of Canada. Ottawa: Parks Canada.

http://publications.gc.ca/collections/collection_2009/pc/R63365-2008E.pdf

Hik, D.S., McColl, C.J., and Boonstra, R. 2001. Why are Arctic ground squirrels more stressed in the boreal forest than in alpine meadows? Ecoscience 8(3):275-288.

https://doi.org/10.1080/11956860.2001.11682654

ICCA (Inuit Circumpolar Council-Alaska). 2015. Alaskan Inuit food security conceptual framework: How to assess the Arctic from an Inuit perspective. Summary and Recommendations Report. Anchorage: ICCA.

https://iccalaska.org/wp-icc/wp-content/uploads/2016/03/ Food-Security-Summary-and-Recommendations-Report.pdf

IPCC (Intergovernmental Panel on Climate Change). 2014. Climate change 2014: Impacts, adaptation, and vulnerability. IPCC Working Group II contribution to the Fifth Assessment Report. Geneva, Switzerland: IPCC. https://www.ipcc.ch/report/ar5/wg2/

Jarosz, L. 2014. Comparing food security and food sovereignty discourses. Dialogues in Human Geography 4(2):168 - 181. https://doi.org/10.1177/2043820614537161
Kenny, T.A., Wesche, S.D., Fillion, M., MacLean, J., and Chan, H.M. 2018. Supporting Inuit food security: A synthesis of initiatives in the Inuvialuit Settlement Region, Northwest Territories. Canadian Food Studies 5(2):73-110.

https://doi.org/10.15353/cfs-rcea.v5i2.213

KFN (Kluane First Nation). 2014. Nourishing our future: An adaptive food security strategy to ensure the cultural and physical well-being of the Kluane First Nation against the impacts of climate change in the Yukon. Whitehorse, Yukon: Arctic Institute of Community-Based Research.

https://static1.squarespace.comstatic/56afc7218259b53bd8383 cb8/t/57520bb2b09f95345f78d30b/1464994867704/FINAL Community+Report_Feb2015.compressed.pdf 2019. About KFN.

http://www.kfn.ca/index.php/community/about-kfn

Kluane First Nation, Government of Canada, and the Government of the Yukon. 2003. Kluane First Nation Final Agreement. Ottawa: Department of Indian Affairs and Northern Development.

http://publications.gc.ca/collections/Collection/R2-291-2003E. pdf

Kral, M.J., Idlout, L., Minore, J.B., Dyck, R.J., and Kirmayer, L.J. 2011. Unikkaartuit: Meanings of well-being, unhappiness, health and community change among Inuit in Nunavut, Canada. American Journal of Community Psychology 48(34):426-438.

https://doi.org/10.1007/s10464-011-9431-4

Lambden, J., Receveur, O., and Kuhnlein, H.V. 2007. Traditional food attributes must be included in studies of food security in the Canadian Arctic. International Journal of Circumpolar Health 66(4):308-319.

https://doi.org/10.3402/ijch.v66i4.18272

Loring, P.A., and Gerlach, S.C. 2009. Food, culture, and human health in Alaska: An integrative health approach to food security. Environmental Science \& Policy 12(4):466-478. https://doi.org/10.1016/j.envsci.2008.10.006

- 2015. Searching for progress on food security in the North American North: A research synthesis and meta-analysis of the peer-reviewed literature. Arctic 68(3):380-392. https://doi.org/10.14430/arctic4509

Loring, P.A., Gerlach, S.C., Atkinson, D.E., and Murray, M.S. 2011. Ways to help and ways to hinder: Governance for effective adaptation to an uncertain climate. Arctic 64(1):73-88. https://doi.org/10.14430/arctic4081

Lune, H., and Berg, B.L. 2017. Qualitative research methods for the social sciences, 9th ed. Harlow, England: Pearson Education Limited.

Manseau, M., Parlee, B., and Ayles, G.B. 2005. A place for traditional ecological knowledge in resource management. In: Berkes, F., Huebert, R., Fast, H., Manseau, M., and Diduck, A., eds. Breaking ice: Renewable resource and ocean management in the Canadian North. Calgary: University of Calgary Press. $141-164$.

Markel, C., and Clark, D. 2012. Developing policy alternatives for the management of wood bison (Bison bison athabascae) in Kluane National Park and Reserve of Canada. The Northern Review 36(Fall): 53-75. 
McConney, P., Cox, S.-A., and Parsram, K. 2015. Building food security and resilience into fisheries governance in the eastern Caribbean. Regional Environmental Change 15(7):1355-1365. https://doi.org/10.1007/s10113-014-0703-z

Nadasdy, P. 2003. Hunters and bureaucrats: Power, knowledge, and Aboriginal-State relations in the Southwest Yukon. Vancouver: UBC Press.

- 2005. The anti-politics of TEK: The institutionalization of co-management discourse and practice. Anthropologica 47(2):215-232.

-2007. Adaptive co-management and the gospel of resilience. In: Armitage, D., Berkes, F., and Doubleday, N., eds. Adaptive co-management: Collaboration, learning and multi-level governance. Vancouver: UBC Press. 208-227.

Natcher, D.C. 2013. Gender and resource co-management in northern Canada. Arctic 66(2):218-221. https://doi.org/10.14430/arctic4293

Notten, G., and Laforest, R. 2016. Poverty reduction strategies in Canada: A new way to tackle an old problem? UNU-MERIT Working Paper \#2016-057. Maastricht, The Netherlands: Maastricht University. 51 p.

https://www.merit.unu.edu/publications/working-papers/ abstract/?id=6131

Nunavut Food Security Coalition. 2014. Nunavut food security strategy and action plan 2014-16. Iqaluit: Nunavut Food Security Coalition.

http://www.tunngavik.com/wp-content/uploads/2014/05/ NunavutFoodSecurityStrategy_ENGLISH.pdf

Olson, M. 2000. Power and prosperity: Outgrowing communist and capitalist dictatorships. New York: Basic Books.

Ostrom, E. 1990. Governing the commons: The evolution of institutions for collective action. Cambridge: Cambridge University Press.

Paci, C.D.J., Dickson, C., Nickels, S., Chan, L., and Furgal, C. 2004. Food security of northern Indigenous peoples in a time of uncertainty. Paper presented at the 3rd Northern Research Forum Open Meeting: The resilient North - Human responses to global change, 15-18 September 2004, Yellowknife, Northwest Territories.

https://ww w.rha.is/static/files/NRF/OpenAssemblies/ Yellowknife2004/3rd-nrf_plenary-4_pp_paci-et-al.pdf

Padilla, E., and Kofinas, G.P. 2014. "Letting the leaders pass": Barriers to using traditional ecological knowledge in comanagement as the basis of formal hunting regulations. Ecology and Society 19(2): 7. https://doi.org/10.5751/ES-05999-190207

Parks Canada. 2000. "Unimpaired for future generations?" Protecting ecological integrity with Canada's national parks. 2 vols. Report of the Panel on the Ecological Integrity of Canada's National Parks. Ottawa: Minister of Public Works and Government Services.

2010. Kluane National Park and Reserve of Canada: Management plan.

http://publications.gc.ca/collections/collection_2010/pc/R64105-94-2010-eng.pdf

. 2018. The Parks Canada mandate and charter. https://www.pc.gc.ca/en/agence-agency/mandat-mandate
Parks Canada, Dän Keyi Renewable Resources Council, Kluane First Nation, and Yukon Environment. 2014. Draft recommendations for moose harvest management in the Kluane/Duke River Moose Management Unit. Whitehorse, Yukon.

Pomeroy, R.S., and Berkes, F. 1997. Two to tango: The role of government in fisheries co-management. Marine Policy 21(5):465-480 https://doi.org/10.1016/S0308-597X(97)00017-1

Reed, M.S. 2008. Stakeholder participation for environmental management: A literature review. Biological Conservation 141(10):2417-2431. https://doi.org/10.1016/j.biocon.2008.07.014

Reedy, K. 2016. Kelp-fed beef, swimming caribou, feral reindeer, and their hunters: Island mammals in a marine economy. Sustainability 8(2): 113 https://doi.org/10.3390/su8020113

Rosol, R., Powell-Hellyer, S., and Chan, H.M. 2016. Impacts of decline harvest of country food on nutrient intake among Inuit in Arctic Canada: Impact of climate change and possible adaptation plan. International Journal of Circumpolar Health 75(1): Article 31127. https://doi.org/10.3402/ijch.v75.31127

Staples, K., and Natcher, D. 2015. Gender, decision making, and natural resource co-management in Yukon. Arctic 68(3):356-366.

https://doi.org/10.14430/arctic4506

Stevenson, M.G. 2004. Decolonizing co-management in northern Canada. Cultural Survival Quarterly 28(1):68-72.

https://www.culturalsurvival.org/publications/culturalsurvival-quarterly/decolonizing-co-management-northerncanada

Theriault, S., Otis, G., Duhaime, G., and Furgal, C. 2005. The legal protection of subsistence: A prerequisite of food security for the Inuit of Alaska. Alaska Law Review 22(1):35-88. https://scholarship.law.duke.edu/alr/vol22/iss1/3

Walch, A., Bersamin, A., Loring, P., Johnson, R., and Tholl, M. 2018. A scoping review of traditional food security in Alaska. International Journal of Circumpolar Health 77(1): Article 1419678. https://doi.org/10.1080/22423982.2017.1419678

Wamukota, A.W., Cinner, J.E., and McClanahan, T.R. 2012. Comanagement of coral reef fisheries: A critical evaluation of the literature. Marine Policy 36(2):481 - 488. https://doi.org/10.1016/j.marpol.2011.09.001

Werner, J.R., Krebs, C.J., Donker, S.A., Boonstra, R., and Sheriff, M.J. 2015. Arctic ground squirrel population collapse in the boreal forests of the southern Yukon. Wildlife Research 42(2):176- 184 .

https://doi.org/10.1071/WR14240

Wesche, S.D., and Chan, H.M. 2010. Adapting to the impacts of climate change on food security among Inuit in the western Canadian Arctic. Ecohealth 7(3):361 - 373. https://doi.org/10.1007/s10393-010-0344-8

Westfall, R. 2010. Dimensions of social inclusion and exclusion in Yukon, 2010. Whitehorse: Dept. of Health and Social Services, Yukon Government. 
Wheeler, H.C., and Hik, D.S. 2014. Influence of shrub canopies on growth rate and pre-hibernation mass of juvenile Arctic ground squirrels. Wildlife Biology 20(4):253-258. https://doi.org/10.2981/wlb.00038

White, G. 2002. Treaty federalism in northern Canada: Aboriginalgovernment land claims boards. Publius 32(3):89-114.

. 2008. "Not the Almighty": Evaluating Aboriginal influence in northern land claims boards. Arctic 61(Suppl. 1): $71-85$.

https://doi.org/10.14430/arctic103

YESAB (Yukon Environmental and Socio-economic Assessment Board). 2005. First Nation participation in assessments. Whitehorse: YESAB.

http://www.yesab.ca/documents/FirstNationFactSheetFinal. pdf

. 2012. The role of YESAB. Whitehorse: YESAB.

http://www.yesab.ca/documents/RoleofYESABfactsheetjuly 2012.pdf
Yukon Fish and Wildlife Management Board. 2019. Yukon Fish and Wildlife Management Board. http://yfwmb.ca

Yukon Government. 2017. Yukon Government socio-economic web portal. http://www.sewp.gov.yk.ca

—. 2018. Dän Keyi Renewable Resources Council. http://www.eco.gov.yk.ca/dan-keyi-renewable-resourcescouncil.html

Yukon Land Use Planning Council. 2018. About us. http://www.planyukon.ca/index.php/about-us

Zanasi, L. 2005. Kluane National Park and Reserve economic impact study. Background Paper No. 3: Economic history of the Kluane Region. Whitehorse: Inukshuk Planning \& Development.

http://www.yukonomics.ca/reports/kluane/KNP_EIA_ Background_3_Econ_History.PDF 